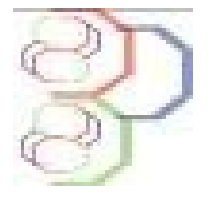

\title{
Effect of softening level on physico-chemical parameters of safou (Dacryodes edulis) pulp and oil grown in Côte d'Ivoire
}

\author{
DJEDJE Blétro Patrick Gérard, KADJI Beugré Romuald Léonce, KONE Fankroma Martial Thierry*, \\ DABONNE Soumaïla \\ Laboratory of Biocatalysis and Bioprocessing, Department of Food Science and Technology, University Nangui \\ Abrogoua, 02 BP 801 Abidjan 02, Côte d'Ivoire. \\ *Corresponding author: fankrom@yahoo.fr
}

Original submitted in on $2^{\text {nd }}$ October 2019. Published online at www.m.elewa.org/journals/ on $31^{\text {st }}$ January 2020

https://doi.org/10.35759/JABs.145.2

\begin{abstract}
Objectives: The African pear (Dacryodes edulis) is an emerging economic fruit tree. Unfortunately, its fruits suffer significant postharvest losses due to their rapid softening. This study aims to determine the effect of post-harvest softening on the physico-chemical qualities of Ivorian safou pulp and oil.

Methodology and Results: Both safou varieties were collected at maturity in Grand-Morie (South-East of Côte d'Ivoire) for physico-chemical analysis. Softening index, moisture, protein and ash contents of $D$. edulis fruit increased from $S_{0}$ to $S_{4}$ levels, while fibre, lipid and carbohydrate contents decreased during softening period. However, no significant variation of nutritional parameters was observed from $S_{0}$ to $S_{1}$, and $S_{3}$ to $S_{4}$. Moreover, the iodine index of safou oil decreased between $S_{0}$ and $S_{4}$, while its saponification index increased. Acid and peroxide indexes increased but remains in compliance with food standards up to softening level $S_{3}$.

Conclusion and application of findings: The postharvest softening significantly influenced the firmness and the proximate components of safou pulp, and the chemical index of its oil. Thus, the postharvest softening effect of safou on proximate components follows a three-phases ripening process. It is the initiation ( $S_{0}$ to $\left.S_{1}\right)$, propagation $\left(S_{1}\right.$ to $\left.S_{3}\right)$ and decline $\left(S_{3}\right.$ to $\left.S_{4}\right)$ that corresponds to the beginning of senescence. These results showed that up to the level $S_{3}$, safou pulp might be useful in the food industry (bakery, pastry), while its oil could be used in food, pharmaceutical and cosmetic industries.
\end{abstract}

Keywords: Dacryodes edulis, postharvest losses, softening, chemical parameters, pulp oil.

\section{INTRODUCTION}

In recent years, attention has focused on nonconventional crops with potential interest for local or industrial development (Akpi, African bush mango and Safou) (Kouamé et al., 2015; Kadji et al., 2016; Ano et al., 2018). Dacryodes edulis or safou is now cultivated in many countries of Central Africa and the Gulf of Guinea (Kadji et al.,
2018). This African pear is an emerging economic fruit tree, which can greatly contribute to reduce poverty in the countries where it is grown (Noumi et al., 2014). Safou fruits are ellipsoid drupes, 4-8 $\mathrm{cm}$ long by $3-6 \mathrm{~cm}$ wide, depending on varieties and origin (Kengué, 2002). Safou pulp would be an important source of oil (Kadji et al., 2018), and thus 
find its place in food, pharmaceutical and cosmetic industries. The pulp powder may be useful in human food industry (bakery, pastry) (Ano et al., 2018). Unfortunately, the potential of safou tree is not fully exploited, because of important postharvest losses as a result of fruit softening (Dossou et al., 2018). Safou fruits usually ripen on the tree and no softening process occurs if they remain attached on the tree. After picking, the ambient conditions deteriorate the edible and commercial qualities of the fruits due to their rapid softening (Dossou et al., 2018). High postharvest losses of safou are registered up to $50 \%$ in just 2-3 days (Mayele, 2010). Thus, the recycling of softened safou in order to transform them as powder or oil could contributed to solve the

\section{MATERIAL AND METHODS}

Sample collection: Based on the morphological characteristics of safou fruits, two varieties were selected: variety edulis and variety parvicarpa (Figure 1, Table 1). The fruits were collected from Grand-Morié (Agneby-Tiassa region), located at southeast of Côte d'lvoire. After harvesting, mature safou fruits were immediately transported in perforated bags to the laboratory and stored at ambient temperature $(27 \pm$ $1.2^{\circ} \mathrm{C}$ ) for 12 days. A total of 200 fruits of each variety were subjected to this study. Samples of stored safou fruits were picked at fixed time intervals, i.e. every three (3) days until the $12^{\text {th }}$ day of storage according to the problem of postharvest losses (Kabantu and Tshiombe, 2011). Scientific research has focused on valorisation and popularization of safou in Côte d'Ivoire. Thus, Kadji et al. (2016) characterized both Ivorian safou varieties, and studied them as ingredients to enrich infant flours. Subsequently, Ano et al. (2018) studied the biochemical and composition of pulp and seeds meal of Ivorian safou obtained after several extraction techniques. The present work is registered into this context. Indeed, there is a lack of data concerning the changes of the physico-chemical parameters of $D$. edulis fruit during the postharvest softening. Therefore, this study aims to determine the effect of the natural softening process on physicochemical qualities of safou pulp and oil.

modified method of Ozdemir and Topuz (2004). Analyses were carried out on 5 softening periods $\left(S_{0}\right.$, $S_{1}, S_{2}, S_{3}$, and $S_{4}$ ) as follows:

- $S_{0}$ corresponds to the sampling carried out when the fruit has been freshly harvested;

- $\mathrm{S}_{1}$ corresponds to the sampling carried out after 3 days storage and which corresponds to the first day of softening when $80 \%$ of the fruits are softened;

- $S_{2}$ corresponds to $S_{1}+3$ days;

- $S_{3}$ corresponds to $S_{2}+3$ days;

- $S_{4}$ corresponds to $S_{3}+3$ days.
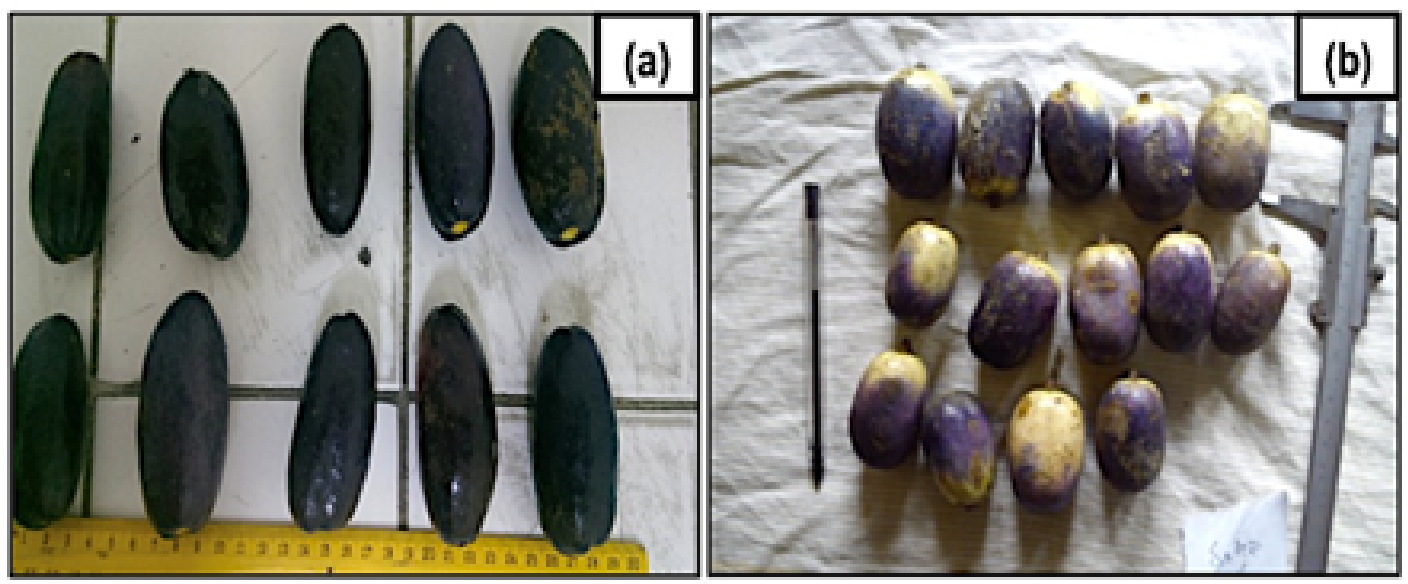

Figure 1: Safou fruits: $D$. edulis variety edulis (a) and $D$. edulis variety parvicarpa (b). 
Table 1: Morphological characteristics for the two varieties of safou fruit

\begin{tabular}{lllll}
\hline Variety & Mass $(\mathbf{g})$ & Length $(\mathbf{m m})$ & Width $(\mathbf{m m})$ & Pulp thickness $(\mathbf{m m})$ \\
\hline edulis & $49.63 \pm 1.51^{\mathrm{b}}$ & $71.23 \pm 2.54^{\mathrm{b}}$ & $37.65 \pm 1.49^{\mathrm{b}}$ & $3.86 \pm 0.42^{\mathrm{b}}$ \\
parvicarpa & $27.34 \pm 1.42^{\mathrm{a}}$ & $38.37 \pm 1.72^{\mathrm{a}}$ & $33.73 \pm 2.15^{\mathrm{a}}$ & $2.92 \pm 0.63^{\mathrm{a}}$ \\
\hline
\end{tabular}

Values are mean of 50 fruits \pm standard deviation. Significant differences at $p<0.05$ are indicated in the same column by different letters.

Texture measurement: According to the modified method of Dossou et al. (2012), a K19500 penetrometer (Koehler Instrument Company, INC, USA) equipped with a piston (47.5 g) was used to measure the texture of the fruits expressed in softening index. For each softening level, one sample of 10 fruits was constituted. This sample was stored at ambient temperature and fruit texture was measured every 3 days up to the $12^{\text {th }}$ day. For each fruit, 12 measurements were taken, uniformly spread along its surface area. Thus, the average of 60 measurements on 5 fruit samples allowed the determination of the softening index.

Chemical analysis methods: Moisture content was determined by drying in an oven at $103 \pm 2^{\circ} \mathrm{C}$ during $4 \mathrm{~h}$ to constant weight (AOAC, 2000). Ash content was determined by incinerating dried samples in a muffle furnace at $550^{\circ} \mathrm{C}$ for $4 \mathrm{~h}$ (AOAC, 2000). Lipid content was determined by the Soxhlet extraction method using hexane as solvent (AOAC, 2000). Protein content was

\section{RESULTS}

Softening index and proximate composition of safou pulp: The softening index and the proximate composition of safou pulp during four softening stages are showed in Table 2. The softening index of $D$. edulis fruit ranged between 0.86 to $3.53 \mathrm{~mm}$ for var. edulis and 0.85 to $2.86 \mathrm{~mm}$ for var. parvicarpa. ANOVA and Duncan test at $p=0.05$ revealed that the safou softening index significantly increased from $S_{0}$ to $S_{4}$, with a slight decrease in intensity from $S_{3}$ to $S_{4}$. Moreover, it is observed in this study that softening index is been significantly different $(p<0.05)$ from one variety to another. Concerning the proximate composition, there is a significant variation $(p<0.05)$ in all parameters studied according to the softening level for the two safou $D$. edulis varieties. However, no significant difference $(p=0.05)$ was observed between $S_{0}$ and $S_{1}$, and between $S_{3}$ and $S_{4}$ softening levels. The moisture content of safou pulp ranged from 41.52 to $47.76 \%$ calculated from nitrogen contents $(\mathrm{N} \times 6.25)$ obtained using the Kjeldahl method (AOAC, 2000). Carbohydrate content was calculated by difference that is by deducing the mean values of other parameters (moisture, ash, lipid, protein and crude fibre) that were determined from 100. Crude fibre content was measured from the loss in weight of the crucible and its content on ignition (AOAC, 2000). Standards ISO were used to determine the iodine value (ISO 3961, 2009), saponification value (ISO 3657, 2003), acid value (ISO 660, 2009) and peroxide value (ISO 3960, 2007) of safou pulp oil.

Statistical analysis: For all analyses, three samples of each variety were used to calculate the mean value and the standard deviation. Data were assessed by Analysis of Variance (ANOVA) and Duncan Multiple Range analysis $(p=0.05)$. The correlation between all parameters was examined by Pearson independence test. Statistical analysis was performed using the Statistica software 7.1 (Stat Soft Inc, Tulsa USA Headquarters).

(var. edulis) and from 41.32 to $47.81 \%$ (var. parvicarpa). Ash contents of safou ranged between 2.95 and $3.33 \%$ (var. edulis and parvicarpa). Protein content varied from 3.34 to $6.83 \%$ (var. edulis) and 3.31 to $6.88 \%$ (var. parvicarpa). Results also shows that these three parameters (moisture, ash and protein) significantly increased $(p<0.05)$ during the postharvest softening from $S_{1}$ (3 days) to $S_{3}$ (9 days). Table 2 shows that lipid content ranged from 31.19 to $37.27 \%$ (var. edulis) and from 28.23 to $34.68 \%$ (var. parvicarpa). Carbohydrate content of safou pulp varied from 10.35 to $12.18 \%$ (var. edulis) and from 13.21 to $15.01 \%$ (var. parvicarpa). Fibre content ranged from 0.54 to $2.72 \%$ (var. edulis) and from 0.54 to $2.71 \%$ (var. parvicarpa). ANOVA and Duncan test at $p=0.05$ revealed that these parameters (lipid, carbohydrate and fibre) significantly decreased during the natural softening process from $S_{1}$ ( 3 days) to $S_{3}$ (9 days). 
Table 2: Proximate composition of safou pulp during the natural softening process

\begin{tabular}{ccccccccc}
\hline Var. SL & $\begin{array}{c}\text { Softening } \\
\text { index } \\
(\mathbf{m m})\end{array}$ & $\begin{array}{c}\text { Moisture } \\
(\%)\end{array}$ & $\begin{array}{c}\text { Ash } \\
(\%)\end{array}$ & $\begin{array}{c}\text { Lipid } \\
(\%)\end{array}$ & $\begin{array}{c}\text { Protein } \\
(\%)\end{array}$ & $\begin{array}{c}\text { Carbohydrate } \\
(\%)\end{array}$ & $\begin{array}{c}\text { Crude } \\
\text { fibre } \\
(\%)\end{array}$ \\
\hline & $\mathbf{S}_{0}$ & $0.86 \pm 0.06^{\mathrm{a}}$ & $41.52 \pm 0.1^{\mathrm{a}}$ & $2.95 \pm 0.02^{\mathrm{a}}$ & $37.27 \pm 0.42^{\mathrm{f}}$ & $3.34 \pm 0.34^{\mathrm{a}}$ & $12.18 \pm 0.18^{\mathrm{c}}$ & $2.72 \pm 0.04^{\mathrm{a}}$ \\
& $\mathbf{S}_{1}$ & $1.78 \pm 0.03^{\mathrm{c}}$ & $41.74 \pm 0.17^{\mathrm{a}}$ & $2.97 \pm 0.01^{\mathrm{a}}$ & $37.24 \pm 0.51^{\mathrm{f}}$ & $3.39 \pm 0.16^{\mathrm{a}}$ & $11.98 \pm 0.21^{\mathrm{c}}$ & $2.70 \pm 0.06^{\mathrm{a}}$ \\
$\mathbf{E}$ & $\mathbf{S}_{2}$ & $2.85 \pm 0.06^{\mathrm{f}}$ & $45.15 \pm 0.23^{\mathrm{b}}$ & $3.15 \pm 0.03^{\mathrm{b}}$ & $33.49 \pm 0.63^{\mathrm{d}}$ & $5.16 \pm 0.13^{\mathrm{b}}$ & $11.53 \pm 0.17^{\mathrm{b}}$ & $1.52 \pm 0.03^{\mathrm{b}}$ \\
& $\mathbf{S}_{3}$ & $3.42 \pm 0.05^{\mathrm{g}}$ & $47.51 \pm 0.12^{\mathrm{c}}$ & $3.32 \pm 0.02^{\mathrm{c}}$ & $31.22 \pm 0.58^{\mathrm{c}}$ & $6.81 \pm 0.11^{\mathrm{c}}$ & $10.58 \pm 0.13^{\mathrm{a}}$ & $0.56 \pm 0.03^{\mathrm{c}}$ \\
& $\mathbf{S}_{4}$ & $3.53 \pm 0.03^{\mathrm{h}}$ & $47.76 \pm 0.21^{\mathrm{c}}$ & $3.33 \pm 0.01^{\mathrm{c}}$ & $31.19 \pm 0.31^{\mathrm{c}}$ & $6.83 \pm 0.19^{\mathrm{c}}$ & $10.35 \pm 0.21^{\mathrm{a}}$ & $0.54 \pm 0.03^{\mathrm{c}}$ \\
\hline & $\mathbf{S}_{0}$ & $0.85 \pm 0.05^{\mathrm{a}}$ & $41.32 \pm 0.22^{\mathrm{a}}$ & $2.95 \pm 0.02^{\mathrm{a}}$ & $34.68 \pm 0.52^{\mathrm{e}}$ & $3.31 \pm 0.22^{\mathrm{a}}$ & $15.01 \pm 0.26^{\mathrm{f}}$ & $2.71 \pm 0.02^{\mathrm{a}}$ \\
& $\mathbf{S}_{1}$ & $1.48 \pm 0.06^{\mathrm{b}}$ & $41.53 \pm 0.31^{\mathrm{a}}$ & $2.97 \pm 0.01^{\mathrm{a}}$ & $33.75 \pm 0.31^{\mathrm{d}}$ & $3.32 \pm 0.31^{\mathrm{a}}$ & $14.74 \pm 0.23^{\mathrm{f}}$ & $2.71 \pm 0.01^{\mathrm{a}}$ \\
$\mathrm{P}$ & $\mathbf{S}_{2}$ & $2.53 \pm 0.03^{\mathrm{d}}$ & $45.17 \pm 0.16^{\mathrm{b}}$ & $3.15 \pm 0.03^{\mathrm{b}}$ & $30.59 \pm 0.43^{\mathrm{b}}$ & $5.19 \pm 0.16^{\mathrm{b}}$ & $14.37 \pm 0.12^{\mathrm{e}}$ & $1.53 \pm 0.04^{\mathrm{b}}$ \\
& $\mathbf{S}_{3}$ & $2.71 \pm 0.05^{\mathrm{e}}$ & $47.69 \pm 0.12^{\mathrm{c}}$ & $3.32 \pm 0.02^{\mathrm{c}}$ & $28.27 \pm 0.45^{\mathrm{a}}$ & $6.83 \pm 0.12^{\mathrm{c}}$ & $13.33 \pm 0.15^{\mathrm{d}}$ & $0.56 \pm 0.02^{\mathrm{c}}$ \\
& $\mathbf{S}_{4}$ & $2.86 \pm 0.04^{\mathrm{f}}$ & $47.81 \pm 0.17^{\mathrm{c}}$ & $3.33 \pm 0.01^{\mathrm{c}}$ & $28.23 \pm 0.51^{\mathrm{a}}$ & $6.88 \pm 0.17^{\mathrm{c}}$ & $13.21 \pm 0.32^{\mathrm{d}}$ & $0.54 \pm 0.01^{\mathrm{c}}$ \\
\hline
\end{tabular}

Values given are mean \pm standard deviation of triplicate determination. Significant differences at $p<0.05$ are indicated in the same column by different letters.

Var.: Variety; SL: Softening level; E: variety edulis; P: variety parvicarpa.

Chemical parameters of safou pulp oil: The variation of the chemical parameters of safou pulp oil during the postharvest softening is presented in Figure 2. During the softening process $\left(S_{0}\right.$ to $\left.S_{4}\right)$, the iodine values of safou pulp oil decreased significantly $(p<0.05)$ from 57.01 to $26.12 \mathrm{mg} / 100 \mathrm{~g}$ in var. edulis and from 58.36 to $28.32 \mathrm{mg} / 100 \mathrm{~g}$ in var. parvicarpa (Figure $2 \mathrm{~A}$ ). Between $\mathrm{S}_{0}$ and $\mathrm{S}_{1}$, a small reduction in iodine value (about 1.5 $\mathrm{mg} / 100 \mathrm{~g}$ ) was observed. Afterwards, a significant decrease in the iodine index (about $17.5 \mathrm{mg} / 100 \mathrm{~g}$ ) was observed from the $3 \mathrm{rd}\left(\mathrm{S}_{1}\right)$ to the 12 th day $\left(S_{4}\right)$. Figure $2 \mathrm{~B}$ shows that saponification index of safou pulp oil increased significantly $(p<0.05)$ during the postharvest softening from $S_{0}$ (day 0 ) to $S_{4}$ (day 12). These values ranged from 212.26 to $287.85 \mathrm{mg} \mathrm{KOH} / \mathrm{g}$ for var. edulis and from 198.24 to $259.43 \mathrm{mg} \mathrm{KOH} / \mathrm{g}$ for var. parvicarpa. A significant increase $(p<0.05)$ was also observed for acid and peroxide indexes of safou pulp oil during the postharvest softening from $\mathrm{S}_{0}$ to $\mathrm{S}_{4}$ (Figures $2 \mathrm{C}$ and $2 \mathrm{D}$ ). Indeed, the acid index values increased from 1.49 to $4.62 \mathrm{mg} \mathrm{KOH} / \mathrm{g}$ (var. edulis) and from 1.48 to $4.18 \mathrm{mg} \mathrm{KOH} / \mathrm{g}$ (var. parvicarpa), while the peroxide index values increased from 3.57 to 8.82 meq $\mathrm{O}_{2} / \mathrm{kg}$ (var. edulis) and from 3.53 to $8.39 \mathrm{meq} \mathrm{O}_{2} / \mathrm{kg}$ (var. parvicarpa) during postharvest softening. Moreover, the results of current study showed that all indexes of safou oil were significantly different $(p<0.05)$ from one variety to another. 

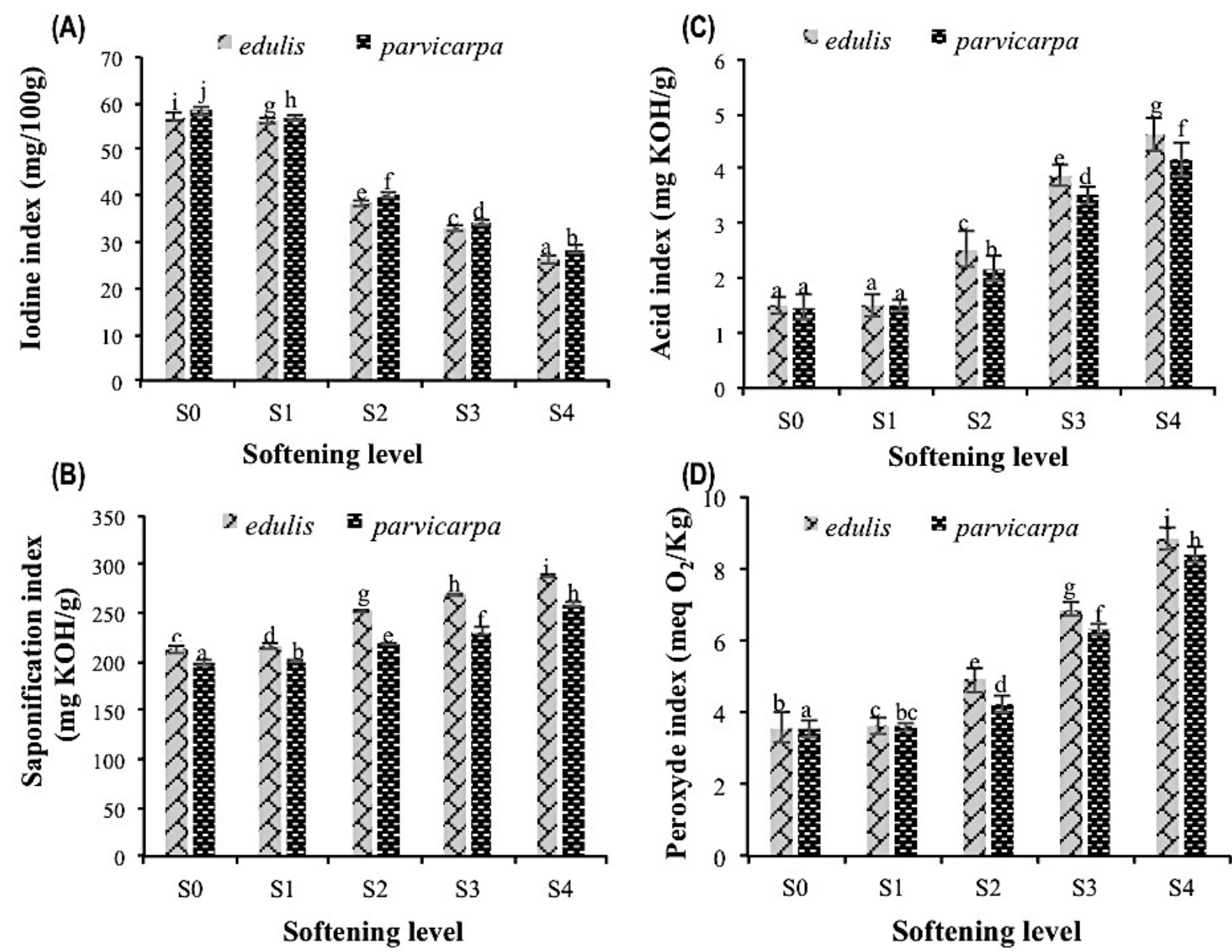

Figure 2: Chemical index of safou pulp oil during postharvest softening: iodine index (A), saponification index (B), acid index (C) and peroxide index (D).

\section{DISCUSSION}

Changes in firmness and proximate parameters of safou pulp during natural softening process: Firmness is an important parameter for measuring the quality of fresh fruits and vegetables. In this study, the softening index $(0.85-0.86 \mathrm{~mm})$ taken on the day of harvest $\left(\mathrm{S}_{0}\right)$ was close to those reported by Dossou et al. (2018) $(0.85 \mathrm{~mm})$ for safou fruits. Between $S_{0}$ (day 0 ) and $S_{3}$ (day 9), a sudden drop in firmness is observed. Afterwards, the firmness loss is gradual until $\mathrm{S}_{4}$ softening level (day 12). Similar observation has been found by several authors who reported that safou softening appeared on the third day of postharvest storage (Kengué, 2002; Silou et al., 2007; Mayele, 2010). According to Dossou et al. (2018), the softening stage is characterized by significant cell wall carbohydrate degradation, and changes during postharvest storage have an impact on safou texture.
This could be attributed to a reduction in insoluble pectin during ripening (Mamiro et al., 2007). Thus, fruit softening is associated with cell wall disassembly (AbuBakr et al., 2003). In D. edulis var. edulis, the softening index was found to be higher than that from $D$. edulis var. parvicarpa. This result indicates that the higher the size, the greater the softening of safou fruits (Dossou et al., 2012). This study also showed that there was no significant difference in all chemical composition of safou pulp between $S_{0}$ (day 0 ) and $S_{1}$ (day 3 ) softening levels. This would correspond to the beginning of softening process. However, moisture, ash and protein contents increased rapidly within $S_{1}$ (day 3 ) to $S_{3}$ (day 9) softening level, when lipid, carbohydrate and fibre contents decreased. This increase could be explained by the propagation of the softening process. Afterwards, from $S_{3}$ (day 9 ) to $S_{4}$ (day 12), the variation 
of the chemical composition became low and not significant. This low variation would be due to the decline of the softening process and the transition period between maturation and senescence. The moisture content of safou pulp (41.32-41.52\%) taken on the day of harvest $\left(\mathrm{S}_{0}\right)$ is close to those observed by Kadji et al. (2016), which was ranged from 43.02 (D. edulis var. parvicarpa) to $46.80 \%$ (D. edulis var. edulis). Moisture content of safou pulp increased with softening times from $S_{1}$ to $S_{3}$. The perishable nature and the rapid degradation of safou fruits could be explained the significant increase observed in their moisture content (Kadji et al., 2016). The increasing of moisture content during postharvest storage was also observed by Ozdemir and Topuz (2004) in avocado and by Dan et al. (2014) in Solanum anguivi berry during postharvesting ripening period. The ash values of the investigated $D$. edulis pulp (2.95-3.33\%) were comparable to those reported by Ndindeng et al. (2012) (2.7\%) and Duru et al. (2012) (2.89-4.16\%) for the same species. In the current study, the ash content also increased with softening times from $S_{1}$ to $S_{3}$. In contrast, Mahmood et al. (2013) reported a decrease from 5.91 to $4.23 \%$ in cherry fruits at three maturity stages. Ash content gives an indication of mineral element in food and it is very important in many biochemical reactions of metabolic processes in the human body (N'Goran et al., 2015). During softening process, safou pulp would then provide essential minerals for body development. The protein content of freshly harvested safous $\left(S_{0}\right)$ was near those observed by Ndindeng et al. (2012) for the same species (about $3 \%$ ). During postharvest softening period, the protein content of safou pulp was also found to increase from $S_{1}$ to $S_{3}$. This would be related to the increase in polysaccharidase activity during ripening (Elhassan and Abu-Goukh, 2016). An increase in protein content (from 4.23 to $5.91 \%$ ) was also found by Mahmood et al. (2013) in cherry fruit at three maturity stages. The high protein content during softening would be beneficial for consumption. The lipid content obtained in this study $\left(S_{0}\right)$ reveals that safou pulp contains high lipid content (37.27\% for var. edulis and $34.68 \%$ for var. parvicarpa). The observed high levels of lipid confirm that the safou fruits are good sources of oils and fats as reported by Duru et al. (2012) and Kadji et al. (2018). However, these lipid levels were found to decrease during postharvest softening period from $S_{1}$ to $S_{3}$. Similar results were reported by Ozdemir and Topuz (2004) in avocado and by Silou et al. (2007) in D. edulis fruits during post-harvest storage. The reduction observed in lipid content during safou storage would be due to the degradation of triacylglycerol during ripening and senescence. Indeed, triglycerides are catabolized by the action of triacylglycerol lipases, which release fatty acids. Then, these fatty acids are decomposed into acetyl-CoA units through $\beta$-oxidation. Acyl-CoA and alcohols are esterified to form a variety of esters which are characteristic volatile flavour components of fruits (Paliyath et al., 2008). The carbohydrate content of the safous studied at $\mathrm{S}_{0}(12.18-15.01 \%)$ are comparable to those reported by Kadji et al. (2016) (14.66-17.82\%) on a related study. A decrease of carbohydrate content was observed from $S_{1}$ to $S_{3}$. This may be explained by the breakdown of some carbohydrate components, the metabolism of the polysaccharides in the cell wall and the starch hydrolysis during the softening process (Wordu and Akusu, 2018). Such a decrease was highlighted by Assemand et al. (2012) in Musa paradisiaca $L$. fruit. Concerning the fibre content of fresh safous $\left(\mathrm{S}_{0}\right)$, the values obtained in this study (around to 2.7\%) are near to those obtained by Kadji et al. (2016), which found 2.70 to $3.13 \%$ of fibre in safou fruits. The softening process resulted in a decrease in fibre content of safou from $S_{1}$ to $S_{3}$. This reduction was also observed in cherry fruits (Mahmood et al., 2013) and in D. edulis fruits (Duru et al., 2012) during maturation stage. According to Mamiro et al. (2007), the decrease in fibre content could be attributed to a reduction in insoluble pectin during maturation involving the action of enzymes.

Changes in chemical parameters of safou pulp oil during natural softening process: The iodine index of the studied safou was found to decrease during softening process from 57.01 to $26.12 \mathrm{mg} / 100 \mathrm{~g}$ and from 58.36 to $28.32 \mathrm{mg} / 100 \mathrm{~g}$ in $D$. edulis var. edulis and in var. parvicarpa, respectively. Between $S_{0}$ and $S_{1}$, a slight decrease (about $0.95 \mathrm{mg} / 100 \mathrm{~g}$ ) in the iodine index was observed. This slight variation in the iodine index suggests that the quality of the studied oil remains interesting from $S_{0}$ to $S_{1}$. From $S_{1}$ to $S_{4}$, a significant decrease in the iodine index was observed. This could be explained by the increasing of oxidative degradation of oil during the storage time (Noumi et al., 2014), thus reducing the amount of double bonds in the oils. Indeed, iodine index is used to quantify the amount of double bonds present in the oil, which reflects the susceptibility of oil to oxidation. It gives information on the unsaturation degree in oil and it is an identity characteristic of native oil. The higher the iodine index, the more unsaturated the oil. In the current study, the observed iodine index after harvest remained in the 
range of edible oils, between 9.37 and $145 \mathrm{mg} / 100 \mathrm{~g}$ (Tan et al., 2002). Concerning the saponification index, an increase was observed between $S_{0}$ to $S_{4}$ from 212.26 to $287.85 \mathrm{mg} \mathrm{KOH} / \mathrm{g}$ and from 198.24 to 259.43 $\mathrm{mg} \mathrm{KOH} / \mathrm{g}$ in $D$. edulis var. edulis and in var. parvicarpa, respectively. This increase could be explained by the breakdown of unsaturated fatty acid chains following oxidation during postharvest storage (Wolff, 1991). These saponification values of safou pulp oils studied are comparable to those of oils currently used in food diet: soybean (188 - 195), cotton oil (188 190), olivine oil (184 -196) and peanut oil (187- 196) (Noumi et al., 2014). The high saponification values in this study are close to those reported by Kadji et al. (2018) for Ivorian safou (173.16 to $215.16 \mathrm{mg} \mathrm{KOH} / \mathrm{g}$ ) and suggest the possibility of industrial applications of safou oil. Acid index determine the use of oil for either edible or industrial utility (Kadji et al., 2018). The acid index of fresh safou $\left(\mathrm{S}_{0}\right)$ is in accordance with those reported by Kadji et al. (2018). Between $S_{0}$ to $S_{4}$ softening level, there is an increase of acid index. This could be due to the increasing of oxidative degradation of oil during storage (Noumi et al., 2014), resulting in an

\section{CONCLUSION}

This study revealed that the postharvest softening induced significant changes in the physico-chemical quality of safou pulp and oil. The natural softening process of safou grown in Côte d'lvoire is quickly initiated and it would occur in three phases: initiation $\left(S_{0}\right.$ to $\left.S_{1}\right)$, propagation $\left(S_{1}\right.$ to $\left.S_{3}\right)$ and decline $\left(S_{3}\right.$ to $\left.S_{4}\right)$. In this respect, the nutritional value of softened safou pulp remains satisfactory during 9 days after harvest

\section{REFERENCES}

Abu-Goukh AA and Bashir A, 2003. Changes in pectic enzymes and cellulase activity during guava fruit ripening. Food Chemistry 83: 213-218.

Ano AARR, Koffi EN, Adima AA, N'da PK, Anin LA, 2018. Composition biochimique et phytochimique des tourteaux des fruits du safoutier (Dacryodes edulis) de Côte d'Ivoire. International Journal of Biological and Chemical Sciences 12(6): 2535-2546.

AOAC, 2000. Official Methods of Analysis of the Association of Analytical Chemists. 17th Edition. Washington, DC, USA.

Assemand KE, Camara F, Kouamé F, Konan V, Kouamé PL, 2012. Caractérisation biochimique des fruits de plantain (Musa paradisiaca L.) variété "Agnrin » de Côte increase in the amount of free fatty acids in oil. Similarly, Dandjouma et al. (2008) reported an increase of acid index during the storage of Canarium schweinfurthii fruits pulp oil. In the current study, the acid index of safou oils (3.51-3.87 mg KOH/g) after 9 days storage $\left(S_{3}\right)$ remain below the recommended value of $4 \mathrm{mg} \mathrm{KOH} / \mathrm{g}$. Therefore, these oils are suitable for edible purpose (Codex Alimentarius, 2005). The peroxide index observed in this study at $\mathrm{S}_{0}$ (around 3.5 meq $\mathrm{O}_{2} / \mathrm{kg}$ ) is comparable to those reported by Kadji et al. (2018) (3.48-4.46 meq $\mathrm{O}_{2} / \mathrm{kg}$ ) and Noumi et al. (2011) (4.58 meq $\mathrm{O}_{2} / \mathrm{kg}$ ) for safou pulp oils. Between $\mathrm{S}_{0}$ to $S_{4}$ softening level, an increase of peroxide index was observed. This increase was also reported by Dan et al. (2014) during the storage of S. anguivi berry. Increase in peroxide index would translate high oxidation of unsaturated fatty acids in oil during storage (Dandjouma et al., 2008). However, the relatively low peroxide values at 9 days storage $\left(S_{3}\right)$, which are well below 10 meq $\mathrm{O}_{2} / \mathrm{kg}$, exhibit the potential use of softened safou oil in food industry (Codex Alimentarius, 1992).

$\left(S_{3}\right)$. In addition, the quality of safou pulp oil remain conformed to the recommended standards for edible oils despite its low oxidative degradation during softening up to $S_{3}$. This shows that the fresh fruit of Ivorian safou is a nutritious food, which could be used for industrial purposes and consumed in various forms 9 days after harvest.

d'Ivoire et évaluation sensorielle de ses produits dérivés. Journal of Applied Biosciences 60: 4438-4447.

Codex Alimentarius, 1992. Programme mixte FAO/OMS sur les normes alimentaires. FAO, Rome, Italie.

Codex Alimentarius, 2005. Alinorm 01/17: Norme pour les huiles végétales portant un nom spécifique, Codex-Stan 210, 14 pp.

Dan CG, Kouassi KN, Ban KL, Nemlin GJ, Kouame PL, 2014. Influence of maturity stage on nutritional and therapeutic potentialities of Solanum anguivi Lam berries (Gnagnan) cultivated in Côte d'Ivoire. International Journal of Nutrition and Food Science 3(2): 1-5. 
Dandjouma AKA, Tchiegang C, Parmentier M, 2008. Evolution de quelques paramètres de qualité physico-chimique de l'huile de la pulpe des fruits de Canarium schweinfurthii Engl. au cours du stockage. International Journal of Biological and Chemical Sciences 2(3): 249257.

Dossou BR, Missang CE, Baron A, Renard CMGC, Silou T, 2012. Factors affecting postharvest preservation of safou (Dacryodes edulis (G. Don) H.J. Lam) fruits. Forests, Trees and Livelihoods 21(1): 44-55.

Dossou BR, Missang CE, Karou SD, Ameyapoh Y, 2018. Relationship between texture and cellwall components of safou (Dacryodes edulis (G. Don) H.J. Lam) fruits at different storage conditions. Journal of Applied Biosciences 125: 12566-12580.

Duru M, Amadi C, Ugbogu A. Eze A, Amadi B, 2012. Phytochemical, vitamin and proximate composition of Dacryodes edulis fruit at different stages of maturation. Asian Journal of Plant Science and Research 2(4): 437-441.

Elhassan SYM and Abu-Goukh AA, 2016. Role of cellulase enzyme in fruit softening during muskmelon fruit ripening. American Journal of Scientific and Industrial Research 7(4): 98105.

ISO 3657, 2003. Animal and vegetable fats and oils. Determination of saponification value. International, Organization of Standardization.

ISO 3960, 2007. Animal and vegetable fats and oils. Determination of peroxide value lodometric (visual) end point determination. International Organization of Standardization.

ISO 3961, 2009. Animal and vegetable fats and oils. Determination of iodine value. International Organization of Standardization.

ISO 660, 2009. Animal and vegetable fats and oils. Determination of acid value and acidity. International Organization of Standardization.

Kabantu MT and Tshiombe VE, 2011. Quelques constantes physiques de l'huile de safou. Editions Universitaires Européennes. 6 pp.

Kadji BRL, Kone FMT, Sika AE, Dabonné S, 2016, Physico-chemical properties of Safou (Dacryodes edulis) fruits grown in Côte d'Ivoire. Journal of Applied Biosciences 105: 10103-10110.

Kadji BRL, Sika AE, Koné FMT, Dabonné S, 2018. Physicochemical properties and composition of safou (Dacryodes edulis) non-conventional oil from Côte d'Ivoire. Journal of Chemical, Biological and Physical Sciences 8(1): 168179.

Kengué J, 2002. Fruits for the future 3. Safou: Dacryodes edulis. Research for Development in Department for International Development. $147 \mathrm{pp}$.

Kouamé NMT, Soro K, Mangara A, Diarrassouba N, Koulibaly AV, Boraud NKM, 2015. Etude physico-chimique de sept (7) plantes spontanées alimentaires du centre-ouest de la Côte d'lvoire. Journal of Applied Biosciences 90(1): 8450-8463.

Mahmood T, Anwar F, Bhatti IA, Iqbal T, 2013. Effect of maturity on proximate composition, phenolics and antioxidant attributes of cherry fruit. Pakistan Journal of Botanic 45(3): 909-914.

Mamiro P, Fweja L, Chove B, Kinabo J, George V, Mtebe K, 2007. Physical and Chemical Mango (Mangifera Indica L.) Fruits varieties of Eastern Tanzania. African Journal of Biotechnology 6(21): 2477-2483.

Mayele D, 2010. Biodiversité morphologique et biochimique du safou (Dacryodes edulis) de Kinshasa et du Bas-Congo en République Démocratique du Congo. Thèse de doctorat, Université de Kinshasa, République Démocratique du Congo.

N'Goran NAM, Ahipo DE, Koné FMT, N'Guessan EJPK, Zoro BIA, Kouamé PL, 2015. Physicochemical properties and mineral composition of four cultivar seed flours from Citrullus lanatus (Cucurbitaceae) cultivated in Côte d'Ivoire. International Journal of Agronomy and Agricultural Research 6(1): 45-53.

Ndindeng SA, Talle, Bigoga J, Kengue J, Boffa J-M, 2012. Predictors of organoleptic quality of boiled and dried pulp of safou (Dacryodes edulis) and the shelf life of its fresh fruits. Fruits 67(2): 127-136.

Noumi GB, Djounja T, Ngameni E, Kapseu C, 2014. Influence of the storage time on the fats and oil composition of safou (Dacryodes edulis) dried pulp. International Food Research Journal 21(5): 1837-1841.

Noumi GB, Njouokam YM, Njiné CB, Ngameni E, Kapseu C, 2011. Effets du séchage sur le rendement et la qualité de l'huile extraite de la pulpe de safou. Tropicultura 29(3): 138-142. 
Nwosuagwu UH, Onuegbu CN, Nkwoala CC, 2009. The chemical properties of African pear pulp at different stages of fruit development. International NGO Journal 4(9): 380-385.

Ozdemir F. and Topuz A., 2004. Changes in dry matter, oil content and fatty acids composition of avocado during harvesting time and postharvesting ripening period. Food Chemistry 86 : 79-83.

Paliyath G, Murr DP, Handa AK, Lurie S, 2008. Postharvest biology and technology of fruits, vegetables, and flowers. Wiley-Blackwell Publishing. 492 pp.

Silou T, Massamba D, Maniongui JG, Maloumbi G, Biyoko S, 2007. Post-harvest losses by natural softening of safou pulp (Dacryodes edulis) in Congo-Brazzaville. Journal of Food Engineering 79: 392-400.
Tan CP and Che Man YB, 2002. Differential scanning calorimetric analysis of palm oil, palm oil based products and coconut oil: effects of scanning rate variation. Food Chemistry 76: 89-102.

Wolf JP, 1991. Analyse et dosage des lipides. In Techniques d'analyses et de contrôle dans les industries agroalimentaires. Analyse des constituants alimentaires. Lavoisier, Techniques et Documentation, France. 221 pp.

Wordu GO and Akusu MO, 2018. Chemical mineral and anti-nutrient composition of plantain (musa paradisiacal) during ripening process. International Journal of Food Science and Nutrition 3(1): 150-153. 